\title{
Втілення в радянському художньому кіно образів «ворога» та «героя» періоду Української революції 1917-1921 рр.
}

\author{
Пижик А. М., Київський національний університет імені Тараса Шевченка
}

Проаналізовано втілення в радянських художніх фільмах 1920-х - 1950-х рр. образів «ворога» та «героя» доби Української революції. Спираючись на підходи історичної імагології, відображено специфіку формування та пропагування кінематографічних образів, тематично пов'язаних із 1917-1921 рр. Підкреслено, що на думку партійних ідеологів кінематограф мав стати знаряддям поширення комуністичної ідеології та формування в суспільстві уявлень про революційне минуле. Встановлено, що зображення революційних подій через призму ідеологічних вимог влади було одним із провідних напрямків радянського кінематографа. Фільми різних жанрів відображали боротьбу більшовиків за встановлення та утримання влади у 1917-1921 рр., формували у глядачів стійкі візуальні образи «ворога» революції та «героя». 3'ясовано, що ці образи мали відмінне змістове наповнення та екранне втілення у різні періоди розвитку радянського кінематографа. Так, у 1920-х роках у художніх фільмах «Остап Бандура» (1924 р.), «Пілсудський купив Петлюру» (1926 р.), «Два дні» (1927 р.), «Звенигора» (1927 р.), «Арсенал» (1929 р.) та ін. «ворогів» представляли підступними, продажними, безжальними і водночас жалюгідними та комічними. «Герої», не дивлячись на непривабливий зовнішній вигляд, показані близькими до глядача та переконаними в перемозі під час боротьби за революційну правду. У 1930-х роках, в умовах сформованої тоталітарної системи, протилежні образи зазнають певних змін і отримують додаткові риси. Так, у фільмах «Щорс» (1939 р.) та «Вершники» (1939р.) «вороги» все більш скритні та лицемірні, а «герої» - відверті, цілеспрямовані, прямолінійні, впевнені в рішеннях і діях партійного керівництва. Встановлено, що головним персоніфікованим «ворогом» у радянському художньому кіно довоєнної доби став Симон Петлюра. У роки німецько-радянської війни та в післявоєнний період у фільмах «Олександр Пархоменко» (1942р.) та «Правда» (1957 р.) «ворогів» зображували менш емоційно, але більш зневажливо - як невпевнених і безвольних, а революційних «героїв», навпаки - свідомими, врівноваженими, які діють за планом, розробленим вождями комуністичної партії. Доведено, що впродовж всього існування радянського кінематографа, протиставлення образів «ворога» і «героя» дозволяло показати неминучість поразки українських національних сил і перемоги більшовиків.

Ключові слова: кінематограф; імагологія; художній фільм; радянська влада; УРСР; С. Петлюра; О. Довженко

\section{Visualization of the image of «enemies» and «heroes» from the period of the Ukrainian Revolution of 1917-1921 in Soviet narrative films}

\section{Pyzhyk A. M., Taras Shevchenko National University of Kyiv}

The Soviet authorities paid a considerable attention to the development of the cinematography. The cinema was recognized in decisions taken by congresses of the Russian Communist Party (Bolsheviks), and in works of party ideologists, as an important tool of influence for masses. The Soviet movies carried an ideological burden - they played a role of party agitators and imposed images of the «heroes» and «enemies» on viewers. The purpose of the article is to examine how the image of «heroes» and «enemies» from the period of revolution was developed in the Soviet narrative films of 1920th-1950th. The analysis of papers and books on the history of Ukrainian cinematography proves that the problem was not properly investigated by researchers. The article, by applying approaches of the historical imagology, explores the process of how the images of «heroes» and «enemies» in the Ukrainian Soviet films were created and popularized. One of the main topics of the Soviet cinema was the history of the revolutionary events, which were presented according to ideological requirements of the authorities. Films of various genres reflected the struggle of the Bolsheviks for the establishment and maintenance of the power in 1917-1921. They formed a stable perception of the images of the «enemy» and «hero» of the revolution. For example, in the 1920th, «enemies» were depicted as insidious, corrupt, ruthless and at the same time - as miserable and comic in such films as «Ostap Bandura» (1924), «Piłsudski bought Petlura» (1926), «Two days» (1927), «Zvenyhora» (1927), «Arsenal» (1929), «Night driver» (1929). Instead, the «heroes» were simple, accessible, open. In the 1930th, when the building of a totalitarian system in the USSR had been completed, the images obtained some additional features. Thus, in Oleksandr Dovzhenko's films «Shchors» (1939) and Ihor Savchenko's «The Riders» (1939), «enemies» became increasingly hidden, insincere and hypocritical, and «heroes» were purposeful, straightforward and confident of victory. In the films made during and after the German-Soviet war «enemies» were depicted contemptuously. They were uncertain and weak-willed. While the revolutionary «heroes», on the contrary, were calm, conscious and acting in accordance with the plan. Such images were embodied in the films «Alexander Parkhomenko» (1942) and «The Truth» (1957). Soviet films impose images of the «enemies» which weak, anti-popular, dependent on external support and struggling against Soviet power in vain. Symon Petlura 
was the main personified «enemy» in the Soviet films. The images of the «heroes» were the embodiment of the glorious revolutionary past, the force of the Soviet power, the victorious progress of the communist revolution. The Soviet cinematography throughout its existence opposed the images of the «enemy» and «hero» and presented the inevitable defeat for one and the victory for the other. Nowadays, the creation of new visual images of «heroes» and «enemies» of the Ukrainian Revolution of 1917-1921 remains an urgent task for Ukraine.

Keywords: cinematography; imagology; narrative film; Soviet authority; Ukrainian SSR; Symon Petlura; Oleksandr Dovzhenko

\section{Воплощение в советском художественном кино образов «врага» и «героя» периода Украинской революции 1917-1921 гг.}

\section{Пыжик А. М., Киевский национальный университет имени Тараса Шевченко}

Проанализировано воплощение в советских художественных фильмах 1920-х - 1950-х гг. Образов «врага» и «героя» времён Украинской революции. Опираясь на подходы исторической имагологии отражено специфику формирования и пропаганды кинематографических образов, тематически связанных с 1917-1921 гг. Подчёркнуто, что по мнению партийных идеологов кинематограф должен был стать орудием распространения коммунистической идеологии и формирования в обществе представлений о революционном прошлом. Установлено, что отображение революционных событий через призму идеологических требований власти было одним из ведущих направлений советского кинематографа. Фильмы разных жанров иллюстрировали борьбу большевиков за установление и удержание власти в 1917-1921 гг., формировали у зрителей устойчивые визуальные образы «врага» революции и «героя». Выяснено, что эти образы имели отличное содержательное наполнение и экранное воплощение в разные периоды развития советского кинематографа. Так, в 1920-х годах в художественных фильмах «Остап Бандура» (1924 г.), «Пилсудский купил Петлюру» (1926 г.), «Два дня» (1927 г.), «Звенигора» (1927 г.), «Арсенал» (1929 г.) и др. «врагов» представляли коварными, продажными, безжалостными и одновременно жалкими и комическими. «Герои», несмотря на неприглядный внешний вид, показаны близкими к зрителю и убеждёнными в победе во время борьбы за революционную правду. В 1930-х годах, в условиях сложившейся тоталитарной системы, противоположные образы претерпевают определённые изменения и получают дополнительные черты. Так, в фильмах «Щорс» (1939 г.) и «Всадники» (1939 г.) «враги» все более скрытные и лицемерные, а «герои» - откровенные, целеустремлённые, прямолинейные, уверенные в решениях и действиях партийного руководства. Установлено, что главным персонифицированным «врагом» в советском художественном кино довоенной эпохи стал Симон Петлюра. В годы германо-советской войны и в послевоенный период в фильмах «Александр Пархоменко» (1942 г.) и «Правда» (1957 г.) «врагов» изображали менее эмоционально, но более пренебрежительно как неуверенных и безвольных, а революционных «героев» наоборот - сознательными, уравновешенными, которые действуют по плану, разработанному вождями коммунистической партии. Доказано, что на протяжении всего существования советского кинематографа, противопоставление образов «врага» и «героя» позволяло показать неизбежность поражения украинских национальных сил и победы большевиков.

Ключевые слова: кинематограф; имагология; художественный фильм; советская власть; УССР; С. Петлюра; А. Довженко

\section{Постановка проблеми.}

B становлення радянської влади в Україні не означало остаточної перемоги більшовиків. Ідеї світової революції і далекого світлого майбутнього залишалися незрозумілими для переважної більшості населення України. Більшовицькі ідеологи поставили стратегічне завдання сформувати нове покоління людей, для яких комуністична ідеологія стане невід'ємною частиною існування. В руках більшовиків українська мова, школа, література, мистецтво виступали засобами впливу на свідомість людей. Поряд із плакатом, скульптурою, театральною виставою важливим знаряддям поширення комуністичної ідеології і засобом формування «нової» людини розглядався кінематограф. Радянські художні фільми несли ідеологічне навантаження, відігравали роль партійного агітатора та пропагандиста, створювали візуальні образи «героїв» i «ворогів» нового ладу та нав'язували їх глядачам.

Український кінематограф розвивався в умовах тотального контролю 3 боку партійно-державної влади і виконував ті завдання, які перед ним ставилися. Революційна тематика довгий час домінувала в радянському кінематографі. Екранні «герої», більшовики чи їх прихильники, наділялися найкращими рисами і впевнено перемагали нікчемних «ворогів» революції. Глядача переконували у перевагах борців за встановлення і збереження більшовицької влади i, натомість, у безперспективності боротьби за створення нерадянської України.

\section{Аналіз досліджень і публікацій.}

Історія українського кіно знайшла широке висвітлення у вітчизняній історіографії. Переваж- 
но зусиллями мистецтвознавців розкрито особливості становлення і розвитку кінематографа в Україні в різні історичні періоди, у тому числі в роки існування СРСР. У радянські часи в узагальнюючих працях 3 історії українського кіномистецтва акцент робився на аналізі окремих періодів розвитку кінематографа, виконанні завдань партії та уряду кіномитцями, характеристиці окремих фільмів [11; 15; 16]. Ще з середини 1920-х рр. у кінознавчих журналах в окремих статтях піднімалися питання втілення у фільмах різних образів, у тому числі радянських «героїв» та «ворогів» революційної доби $[1 ; 10 ; 22]$. Інтерпретація образів мала відповідати ідеологічним вимогам комуністичної партії до відображення революційних подій і трактування ролі тих чи інших політичних діячів у 1917-1921 pp.

На відміну від праць радянських авторів, американський кінознавець українського походження Б. Берест у своїй «Історії українського кіно» (1962 р.) звернув увагу на своєрідність і неповторність національного кінематографа, висвітлив творчі здобутки та мистецькі поразки, показав негативний вплив партійного диктату і втручання влади в діяльність кіномитців [4]. Важливе місце в його роботі відводилося аналізу окремих фільмів i їх значенню для розвитку українського кіномистецтва, в тому числі художніх фільмів, які втілювали образи революційної доби.

Праці з історії українського кінематографа, які з'явилися в роки після відновлення незалежності України, характеризують загальні тенденції розвитку кіно в різні історичні періоди, творчість кінорежисерів, здобутки і втрати національного кіномистецтва $[3 ; 14 ; 21]$. В окремих роботах вітчизняних кінознавців та дослідників 3 діаспори приділяється значна увага характеристиці художніх фільмів [9; 13; 29]. Реалізація державної політики у кінематографічній сфері аналізується в працях О. Кузюк, Р. Росляка, Я. Примаченко [18; $24 ; 26 ; 27]$. Проте автори не ставили перед собою завдання розкрити втілення, а тим більше протиставлення, окремих образів у фільмах.

Проблема відображення кінематографістами історії України піднімається у працях Л. Брюховецької $[5 ; 6 ; 7]$. Серед різних аспектів екранної репрезентації історії України вона аналізує умови створення, сюжет, значення художніх фільмів, присвячених 1917-1921 рокам, які, власне, формували позитивні та негативні конкретні чи узагальнені образи діячів революції.

Вивченням формування в національних культурах образів «свого» і «чужого» займаються до- слідники в межах міждисциплінарного напряму імагології, яка почала розвиватися 3 другої половини XX ст. [8; 17; 23]. Однак у роботах вітчизняних представників цього напряму відсутній аналіз кінематографічних образів «свій-герой» та «чужий-ворог» періоду революціï 1917-1921 рр., що формувалися у радянських художніх фільмах.

Аналіз наукової літератури засвідчує, що дана проблема не була належним чином опрацьована вченими. У зв'язку з чим метою статті є дослідження еволюції втілення в радянських художніх фільмах 1920-х - 1950-х рр. образів «ворога» та «героя» революційної доби.

\section{Виклад основного матеріалу.}

Впродовж усього існування радянської влади комуністичні ідеологи приділяли значну увагу розвитку кінематографа. Загальновідомими є слова В. Леніна у розмові з А. Луначарським про кіно як найважливіше 3 мистецтв. Сам же нарком освіти РСФРР А. Луначарський, доповідаючи на Всесоюзній кінонараді в 1924 р., висловив думку, що кінематограф виступає зброєю, яку можна використовувати для випливу на маси i, в порівнянні 3 іншими видами мистецтва, кіно дешевше, воно портативне i наочне [20, с. 35-38]. Інший лідер більшовицької партії, Л. Троцький у 1923 р. у статті «Церква, водка і кінематограф» наголошував, що кінематограф найкращий інструмент пропаганди і має стати знаряддям комуністичного виховання. До того ж кіно, як він зазначав, може допомогти витіснити розваги, пов'язані зі вживанням алкоголю, запропонує населенню нову театралізовану обрядовість, замість церкви, і наповнить державний бюджет додатковими коштами [30].

У резолюціях XII (1923р.) та XIII (1924 р.) з'іздів РКП(б) кіно окреслювалося як один із найважливіших інструментів впливу на маси, який більшовики повинні контролювати [19, с. 221-222, 264]. Комуністична партія визначала політику розвитку кінематографа. Відповідальні за цю сферу державні інституції безпосередньо їі втілювали та наглядали за діяльністю всіх, хто був пов'язаний із кіномистецтвом.

На думку партійних ідеологів, кінематограф мав стати не тільки засобом агітації і пропаганди, мобілізації населення на впровадження рішень партії та уряду, а й знаряддям формування в суспільстві уявлень про революційне минуле, бажане сьогодення і світле майбутнє.

Зображення історії революційних подій через призму ідеологічних вимог влади було однією 3 провідних тем радянського кінематографа. Фільми різних жанрів, від комедій до бойовиків, відо- 
бражали боротьбу більшовиків за встановлення та утримання влади у 1917-1921 рр., формували у глядачів стійкий образ «ворога», який зазнав поразки, і образ «героя»-переможця. I «вороги», i «герої» наділялися певними характерними рисами, які змінювалися та доповнювалися на різних етапах розвитку радянського кінематографа.

Образи «ворогів» в історико-революційних фільмах уособлювалися в персоналіях лідерів Української революції чи узагальнювалися в уявних типових представниках певних соціальних станів - національної інтелігенції, селян, військових. Натомість «герої» у цих фільмах реалізовувалися через збірні образи пролетарів, рядових партійців, червоноармійців, чекістів, селянської бідноти, які при підтримці РКП(б) досягали перемоги.

У різні роки образи «ворогів» і «героїв» мали різне змістове наповнення та екранне втілення. У 1920-pp. у художніх фільмах для глядачів, які нещодавно самі були свідками зображуваних подій, «ворогів» представляли підступними, продажними, безжальними і водночас жалюгідними та комічними. «Герої», не дивлячись на часто непривабливий вигляд, прості, доступні, переконані в перемозі в боротьбі за революційну правду.

У 1930-х рр., в умовах сформованої тоталітарної системи, протилежні образи зазнають певних змін і отримують додаткові риси, відповідно до духу часу. Так, «вороги» все більш приховані, нещирі, лицемірні і фальшиві, а «герої» відверті, цілеспрямовані, часто прямолінійні і, що важливо, впевнені в мудрому партійному керівництві.

У роки німецько-радянської війни та в післявоєнний період «ворогів» зображували менш емоційно, але більш зневажливо - як хитрих, невпевнених, безвольних. Революційних «героїв» навпаки - спокійними, свідомими, які діють за планом, розробленим вождями комуністичної партії.

Революційна тематика 3'являється в радянських художніх фільмах під час діяльності Всеукраїнського фотокіноуправління (ВУФКУ). Події 1917-1921 pр. в Україні вперше знайшли відображення у картинах В. Гардіна «Отаман Хміль» (1923 р.) та «Остап Бандура» (1924 р.). У першому фільмі зображувався перехід «буржуазного» інтелігента на бік радянської влади. Другий фільм показував вплив робітника, «стійкого і послідовного революціонера», на неписьменного селянина, який стає свідомим борцем за «світле майбутнє» [21, с.58]. Надалі саме революційна тематика буде найбільш широко представлена в українському «німому» кіно. Детективи, бойовики, ко- медіï, дитячі фільми присвячувалися реальним та вигаданим подіям громадянської війни. Серед низки фільмів, які зображували революційні часи, найбільш відомими стали картини «Укразія (Сім плюс два)» (1925 р., реж. П. Чардинін), «Два дні. Батько й син» (1927 р., реж. Г. Стабовий), «Арсенал» (1929 р., реж. О. Довженко), «Нічний візник» (1929 р., реж. Г. Тасін), «Перекоп» (1930 р., реж. І. Кавалерідзе).

Надмірне захоплення сценаристів та режисерів революційною проблематикою навіть змусило керівництво ВУФКУ взагалі вилучити тему громадянської війни з орієнтованого плану кіновиробництва на 1928/1929 р. [34, с. 17]. Тільки після втручання вищих партійних органів тема революції була таки до нього внесена [25].

Художні фільми, які присвячувалися подіям 1917-1921 рр., показували різні епізоди боротьби більшовиків проти прихильників відновлення української державності та нав'язували глядачам трактування образів реальних діячів тієї доби та вигаданих осіб з узагальненими характеристиками. Окремі історичні події, факти, діяльність людей знаходили відповідне зображення в художніх картинах. Так, характеризуючи значення картини «Трипільська трагедія» (1926 р., реж. О. Анощенко-Анод), критики відмічали, що це перший фільм 3 історії українського комсомолу і водночас «найяскравіший малюнок 3 історії українського зоологічного націоналізму, що вмер, і що ніколи вже більш не повернеться» [33]. Головними дієвими особами фільму, за сценарієм Г. Епіка, мали стати герої революції - робітники міста Києва, які не вагаючись віддали своє життя для перемоги трудящих. Образи «героїв» втілювали наче й реальних осіб, але разом із тим узагальнювали кращі риси всіх борців за революцію. Натомість образи «ворогів» показані зовні навіть схожими на реальних діячів, як отаман Зелений, але підступними, підкреслено безжальними і максимально відразливими. Дослідник Л. Госейко, подаючи інформацію про цей фільм, наголошував, що в ньому зображувалися не тільки нелюд-отаман, а й свавільне петлюрівське військо, яке знущається над жінками, гвалтує дівчат, спалює комсомольців і танцює гопака на їхніх могилах [9, с. 35].

Головним персоніфікованим «ворогом»у радянському художньому кіно довоєнної доби став Симон Петлюра. Саме він втілював найгірші риси ворожого образу - зраду, продажність закордонним ворогам України, підступність, нещирість, заздрість. Образ екранного «ворога-Петлюри» починає формуватися у 1926 р. із фільму режисерів 
Георгія Стабового та Акселя Лундіна «П.К.П. Пілсудський купив Петлюру» за сценарієм Г. Стабового та Я. Лівшиця. Фільм починається із показу С. Петлюри, якого грає Микола Кучинський. Головний отаман у зимовому одязі, з гордо закинутою головою і зверхнім поглядом. У своїх записках «консультант» цього фільму - Ю. Тютюнник - описав обрання актора на роль С. Петлюри так: «... я вибрав Кучинського, бо він був найменше схожий на живого Петлюру. Насамперед, Кучинський майже вдвоє більший від Петлюри і з екрану на глядача безумовно робить приємніше враження, ніж робив би сам Петлюра» [31].

Образ голови Директорії УНР показано із сарказмом. Через весь фільм проходить штучність, показовість, театральність «Українського Наполеона». Вказується на те, що бажання власного збагачення С. Петлюри, а зовсім не піклування про інтереси українського народу, змушує його діяти. Водночас підкреслюється його марнотратство - витрачання коштів на проведення показових раутів [28]. Йому протиставляється образ «бандитського ватажка» - Ю. Тютюнника, який грає у фільмі самого себе, генерал-хорунжого армії УНР. Керівники війська УНР стають ворогами не поділивши владу. Мета авторів фільму - висміяти боротьбу за УНР, показати зневажливо керівників українського національного руху. Загалом, українські бійці в стрічці зображені недолугими й невпевненими, шпигунами і п’яницями. «Зрадники, кар'єристи, йолопи, інтригани, алкоголіки, злочинці і наркомани - ось хто повинен був з'явитися перед масовим глядачем на екрані, замість тих, що так чи інакше репрезентували ідею української державності й тих, що власною кров'ю писали історію українського народу» - писав пізніше у спогадах Ю. Тютюнник [31].

Як зауважила дослідниця Л. Брюховецька, окремі персонажі фільму, які створюють образи українських підпільників, нагадують російських купців, а не представників національної інтелігенції [7, с. 315]. Керівники національного підпілля збираються у Софіївському соборі в Києві, але попри патетичну риторику, всього бояться; заявляють про свої великі плани, а реально нічого зробити не можуть. За кордоном, отримавши гроші на організацію і проведення повстання, один із керівників підпілля Федір Дністро, якого грає Д. Ердман, витрачає кошти на випивку і гулянку, у п'яному угарі співає гімн «Ще не вмерла Україна». Його образ викликає сміх і відразу у глядачів. Натомість зображення чекіста, який проникає в уенерівське підпілля, відрізняється від представників національної інтелігенції. Він простий звичний не то робітник, не то селянин, але знає, яке перед ним стоїть завдання, і впевнений, що з ним справиться.

Військовим керівникам УНР та воякам республіканської армії протиставляється образ більшовицького командира Г. Котовського і котовців, які, на відміну від перших, діють злагоджено, дисципліновано, забезпечують порядок і впевнено здобувають перемогу. У глядача складається враження, що по-іншому і бути не могло.

Автори фільму через формування зневажливих образів представників українського національного руху намагаються довести безперспективність боротьби за українську національну державність і неминучість поразки ворогів радянської влади.

Символічне протиставлення образів представника українського національного руху і переконаного більшовика подано у фільмі О. Довженка «Звенигора» (1927 р.), який став етапним не тільки для митця, а й для всього українського кінематографа [5].

Тогочасна критика писала: «... «Звенигора» $\epsilon$ глибоко національним фільмом, фільмом нації, що відроджується, фільмом нації, що будує соціалізм» [2]. Образ діда, у виконанні актора М. Надемського, з'єднував у єдине ціле історію України з давніх часів і до початку індустріалізації. В той же час чітко відображується в картині і протистояння «героїв» та «ворогів» революційних років. Втілюють протилежні образи онуки віковічного діда - Остап (актор Л. Подорожний) i Тиміш (актор С. Свашенко). Український патріот Остап зображений вайлуватим, на вигляд простодушним, але жорстоким бандитом, який грабує рідне село, і театрально нещирим в еміграції. Його цікавлять у першу чергу скарби і гроші, за які він готовий діда відправити на смерть. А більшовик Тиміш, хоч і вбиває заради революції свою кохану, однак стає символом позитивних змін і народження нового суспільства. Саме він знаходиться у потязі, який рухається у «світле майбутнє», і забирає діда 3 собою. Глядач мав усвідомити за ким перемога, а хто приречений на поразку.

Сам О. Довженко незабаром після виходу фільму написав про протиставлені образи: «Кричу я, сміючись, нікчемному дідовому внукові у Прагу: «Ти, марнотратнику! Здихай у своїй еміграції!». А сам з другим унуком дідовим, приятелем і товаришем, з яким 1917 року подавав братню руку через багнети німецьким товаришам, веду наш могутній поїзд уперед, до нових досягнень пролетарської праці» [12, с. 43]. 
Образ «героя» Тимоша перейшов разом із актором С. Свашенком у наступний фільм О. Довженка «Арсенал» (1928р.). Після переглядів радянською цензурою чорнового варіанту сценарію фільму «Арсенал» О. Довженку запропонували спрямувати картину проти «найлютіших ворогів українського народу, проти націоналістів усіх мастей, викривати їхнє лицемірство, продажність, зрадництво» [4, с. 75]. Режисеру довелося мистецькими засобами втілювати це завдання. Так, перед глядачами постає сцена коли на Софійському майдані маса народу виступає на підтримку Української Народної Республіки - це студенти, вчителі, кооператори, актори, діячі церкви. На все це театралізоване дійство із посмішкою дивляться представники пролетаріату, які не кричать про свої завдання, а готуються до захоплення влади. Вони впевнені у своїй правоті, рішучі, на їх боці правда, яку неможливо знищити.

Знаменна сцена розстрілу - нерішучий представник української інтелігенції, у якого трусяться руки, не може спокійно вбити людину, хоч та і ворог української державності. Натомість зображено твердість більшовика і його готовність без будь-яких сентиментів, навіть із посмішкою, застрелити класового ворога. Водночас показано безсмертя «героя» Тимоша, який є уособленням незламності пролетаріату в боротьбі за справу революції.

В окремих відгуках про фільм зустрічалися твердження, що головний герой не персоніфікований, а справжній герой - це маса, колектив [32] Але у О. Довженка через обидва фільми проходить героїзація саме образу переконаного бездоганного революціонера, якого втілює Тиміш. Образ Тимоша виступає уособленням більшовицького месії, який долає смерть і стає спасителем, рятівником, покликаним внести у поруйнований світ ідею впорядкованості [21, с. 66-67]. Натомість прихильники ж українського національного руху приречені в протистоянні з новим світом на поразку, оскільки втілюють стару селянську Україну. Саркастично зображено у фільмі українську президію на одному із форумів. Ні одного позитивного образу: практично всі насуплені, пихаті, злорадно посміхаються і викликають відразу в глядачів. 3 іншого боку їм протиставляється образ головного героя серйозного, впевненого, рішучого, здатного повести за собою інших.

У ще одному знаменитому фільмі О. Довженка «Щорс» (1939р.) проявилися нові підходи до формування образу «героя». Про комуністичне майбутнє мріють і за нього борються головний герой картини командир Богунівського полку М. Щорс, у виконанні Євгена Самойлова, та командир Таращанського полку В. Боженко, якого грає Іван Скуратов, рядові бійці. Для забезпечення більш емоційного сприйняття фільму глядачами вводяться сцени, коли наречена під час весілля залишає свого нареченого і йде за бійцем із загону М. Щорса, а мати віддає своїх дітей у полк богунівців, адже за ними правда, натхнення та історія [35, с. 115].

М. Щорс став символом переконаного в своїй правоті більшовика, який не знає ніяких сумнівів і беззастережно вірить у перемогу світової революції. Дослідник з української діаспори Б. Берест вважав, що в образі Щорса О. Довженко сконцентрував характерні риси героїв своїх попередніх фільмів і водночас свій власний темперамент, іронію, світогляд. Хоча головний герой фільму, на думку дослідника з української діаспори, вийшов внутрішньо не виправданим і мало переконливим [4, с. 93-94]. В образі «героя» В. Боженка можна знайти характерні для всіх українців риси - хитруватість, наївність, почуття гумору, у той же час він втілює ненависть до експлуататорів, віру в перемогу над класовими ворогами та дружбу з Росією. Кінокритики, характеризуючи образи головних персонажів, ще у 1939 р. зазначали: «Стрімкий, натхнений вірою у перемогу соціалізму, вірою в силу народу, до кінця володіє собою, до кінця точний у вчинках і діях Щорс і присадкуватий, широкоплечий, з лукавинкою і стихійною неврівноваженістю батько Боженко» [35, с.115].

Образи борців за світле комуністичне майбутне настільки переконливі, що не викликали сумнівів у глядачів у їх достовірності. Дослідник Л. Госейко наводив факт отримання О. Довженком листа від селянської сім'ї, в якому просили переконати Савку Троянова (актор О. Хвиля) повернутися додому. Але це був вигаданий персонаж, якого ніколи не існувало [9, с. 98]. на малоосвічене населення фільми сильно впливали, а отже і образи, які формувалися у фільмах, сприймалися беззастережно, без жодної критики, без усвідомлення їх фіктивності.

Водночас образи «ворогів» стають більш різноманітними в порівнянні 3 попередніми фільмами. Це вже не тільки прихильники незалежної України на чолі з С. Петлюрою, які в більшості не знають за що конкретно воюють, але й військові спеціалісти, яких призначив Л. Троцький, i «нейтральні», яких представляли як найнебезпечнішого ворога.

Симон Петлюра, образ якого втілює Георгій Полєжаєв, зображений істеричним, який не говорить, а лише викрикує, не знає як діяти, щоб 
зупинити наступ більшовиків, вимагає конкретних пропозицій від присутніх, оголошує по суті антинародну програму. Всіляко демонструється зверхнє ставлення С. Петлюри до колег. Інші члени Директорії показані на засіданні невпевненими, безсилими, безнадійно сумними. Вони пропонують як засіб протидії більшовикам провести молебні у київських храмах, домогтися визнання УНР Америкою, хоча б навіть за гроші. Тільки В. Винниченко, екранний образ якого втілює Дмитро Мілютенко, пропонує розчарованим, але спокійним тоном, що спиратися треба на військо і що необхідно скликати трудовий конгрес. Із повідомленням офіцера, що Щорс уже під Києвом, всі члени Директорії заклякли. Глядачі мали прийти до логічного висновку про відсутність авторитету i підтримки населення в такого уряду.

Зображення успішних дій колективного «героя» проти ворогів революції - гетьманців, німецьких окупантів - міститься у фільмі I. Савченка за романом Ю. Яновського «Вершники» (1939 р.). Режисер формує образи лідера партизанів сталевара Чубенка (актор Л. Свєрдлін), який самовіддано бореться за революційні ідеали, та селянина Недолі (актор С. Шкурат), свідомість якого змінюється під впливом німецького свавілля. Організований робітниками партизанський загін, користуючись широкою підтримкою українського населення, успішно протистоїть німецьким військам. Колективізм, самопожертва, готовність за ідею вбити рідного брата характеризують «героїв» фільму. Натомість представники українського національного руху у фільмі показані поверхово. Вони постають віроломними прислужниками німецьких окупантів, які нещадно вбивають людей, знищують цілі села. «Вороги» фальшиві, дволикі, готові зраджувати власний народ.

У роки німецько-радянської війни, перебуваючи в евакуації, Київська кіностудія спільно iз Ташкентською кіностудією випустила фільм «Олександр Пархоменко» (1942 р., реж. Л. Луков). Історико-біографічна картина, присвячена подіям 1918-1921 рр., також формує образ революційного «героя» - військового керівника Олександра Пархоменка (О. Хвиля). Йому протиставляється образ Нестора Махна (Б. Чирков). В образі Пархоменка втілюються традиційні риси радянського «героя»: дисциплінованість, самопожертва, переконаність у своїй правоті, відданість комуністичній ідеї, беззаперечне виконання завдань партії. Натомість Н. Махно крім зовнішньої непривабливості, ще й акумулює традиційну для «ворогів» підступність, ігнорування інших, любов до грошей, зрадливість, безпринципність, неповагу до українців. Хоча дослідник Л. Госейко відмічав, що головний герой виглядає, як це не дивно, менш мотивованим у поведінці, ніж Н. Махно [9, с. 113]. Фільм носив відверто агітаційний характер і мав мобілізовувати на боротьбу $з$ ворогом, пропагував готовність загинути за комуністичні ідеали.

У післявоєнний час фільмів на революційну тематику стало вироблятися менше, у порівнянні 3 1920-1930 рр. Так, у фільмі «Правда» (1957 р.) режисерів Віктора Добровольського та Ісаака Шмарука за п’єсою О. Корнійчука образи «ворогів» виведені не настільки гротескно, як у попередній період. Перед глядачем постають Михайло Грушевський (С. Петров), Володимир Винниченко (Г. Бабенко), Симон Петлюра (Ю. Лавров), які зображені менш емоційно у зіставленні 3 довоєнними фільмами, але вони так само не впевнені у своїх силах, розраховують лише на фінансову і військову підтримку з-за кордонну.

Образи опонентів радянської влади непривабливі, корисливі, нещирі. Так, В. Винниченко заявляє, що українська нація є відсталою. У той же час портрети з його зображенням продаються по 1 карбованцю, але не користуються попитом у населення. Також голова Генерального Секретаріату сперечається з М. Грушевським і С. Петлюрою через їх нехтування пролетаріатом. «Український Юлій Цезарь» С. Петлюра зображений самовпевненим, 3 манією величі, однак він здатен лише говорити, а нічого реального більшовикам протиставити не може.

Натомість формується образ нового «ворога» - зрадника, який з'являється у середині більшовицької партії в Україні. Він реалізовується в образі Георгія П'ятакова (О. Дубов), який вносить розкол у середовище переконаних безкомпромісних більшовиків. Г. П'ятакову протиставляється посланець В. Леніна в Україні - Юрій Коцюбинський (В. Черняк). Образи «вождів» $\mathrm{i}$ «ероїв» у цьому фільмі трафаретні, чіткі, переконані у правильності рішень В. Леніна і партії, готові виконувати поставлені завдання будь-якою ціною.

Поступово в радянському кінематографі образ «ворога» періоду революції знівелювався і перестав відігравати таку пропагандистську роль, як у довоєнні десятиліття. Після німецько-радянської війни головним «ворогом» у кінематографі стають окупанти, зрадники, колаборанти. Героїчні традиції примножують воїни Червоної армії, партизани і підпільники, ветерани. 
Образ «ворога» узагальнений чи персоніфікований (С. Петлюра), сформований радянською історіографією та кінематографом, довго залишався домінуючим у свідомості громадян, навіть вже після відновлення незалежності України. Якщо історикам вдалося розвінчати нав'язані міфи про боротьбу українців за відновлення та збереження своєї державності у 1917-1921 рр., то у вітчизняному художньому кіно до останнього часу не було фільмів, які б формували новий образ українських героїв революційної доби.

Тільки у 2016 р., за результатами восьмого конкурсного відбору, Державне агентство України 3 питань кіно уклало контракт із виробником про надання державної фінансової підтримки на виробництво художнього фільму «Таємний щоденник Симона Петлюри». Загальний бюджет стрічки, яку знімав режисер О. Янчук, становив майже 48 мільйонів гривень. I хоч визначений жанр фільму історико-біографічний, а науковим консультантом виступив професор В. Сергійчук, у його основу покладено вигаданий сценаристами «щоденник», а не реальні історичні документи та праці С. Петлюри. Метою фільму є не відтворення достовірних історичних подій, а показ нового образу Голови Директорії УНР в авторській інтерпретації. За словами сценариста М. Шаєвича, автори фільму намагаються «переконати людей, котрим майже 70 років втокмачували, що Петлюpa - злодій, бандит, котрим лякали дітей, що він $\epsilon$ справжнім українським лідером». Фільм має вийти на екрани у 2018 р. [36].

У вересні 2016 р. одним із переможців дев'ятого конкурсного відбору Держкіно у сесії ігрових тематичних фільмів (до 100-річчя проголошення Української Народної Республіки, до 100-ї річниці Бою студентів під Крутами) став проект повнометражного художнього фільму «Крути 1918». Загальна вартість виробництва кінокартини 52 мільйони гривень, із них держава профінансувала половину. Прем'єра фільму режисера Олексія Шапарєва за сценарієм Костянтина Коновалова очікується у грудні 2018 р. Фільм відображає трактування сценаристом і режисером реальних історичних подій і присвячений героїчним діям молодих патріотів, які стали на захист україн- ської державності у протистоянні з більшовиками. Звичайно, недостатньо лише показати героїв Крут і ворогів України, необхідно щоб фільм зацікавив глядачів і відповідав сучасному рівню кіномистецтва.

\section{Висновки.}

Таким чином, радянський кінематограф послідовно формував образи «героїв» та «ворогів» революції, які наділялися визначеними владою характерними рисами і нав'язувалися глядачам.

Впродовж усього існування радянського кінематографа протиставлення образів «ворога» $\mathrm{i}$ «героя» дозволяло показати неминучість поразки одних і перемоги інших. «Вороги» у більшій чи меншій мірі уособлювали слабкість, антинародність, неповноцінність, залежність від зовнішньої підтримки і безперспективність боротьби проти радянської влади. В свою чергу «герої» на різних рівнях були втіленням славного революційного минулого, переможного поступу світової комуністичної революції, сили і розквіту радянської держави. Співчуття «вороги» у глядача не викликали, навпаки, вони отримували загальний осуд, а у фільмі ще й заслужене покарання за те, що пішли проти народу. Ніякого страху перед ворогами не могло виникнути. Натомість «герої» плекали відчуття єдності 3 переможцями, впевненості в сьогоднішньому дні, якому покоління глядачів зобов'язане революційним звитягам минулого. Формувалася впевненість у тому, що такі самі герої живуть і зараз серед сучасників.

У межах однієї статті неможливо комплексно висвітлити означену проблему і проаналізувати всі художні фільми, які присвячувалися революційній тематиці. Втілення різних образів «свого-героя» та «чужого-ворога» у кінематографі потребує подальшого вивчення у межах історичної імагології як окремого напрямку міждисциплінарних досліджень.

Формування нових візуальних образів «героїв» і «ворогів» Української революції 1917-1921 рр. залишається надзвичайно актуальним завданням для сучасної української держави. Саме високоякісне мистецьке втілення дозволить створювати й пропагувати образи українських героїв, розвінчувати радянські міфи, об’єднувати суспільство спільним минулим. 


\section{БІБІЛІОГРАФІЧНІ ПОСИЛАННЯ}

1. Авенаріус Г. А. Проблема художнього образу у фільмах О. П. Довженка / Г. А. Авенаріус // Кіно. - 1936. - № 4. - С. 18-23.

2. Бажан М. Легенди та історія / М. П. Бажан // Кіно. - 1927. - № 21-22. - С. 2.

3. Безклубенко С. Д. Українське кіно: начерк історії / С. Д. Безклубенко. - Київ: КНУКіМ, 2001. - 170 с.

4. Берест Б. Історія українського кіна / Б. Берест. - Нью-Йорк: Наукове товариство ім. Т. Шевченка, 1962. - 272 с. 5. Брюховецька Л. І. «Звенигора»: оволодіння історичним часом // Кінорежисер світової слави: зб. ст. - Київ: Логос, 2013. - С. 19-53.

6. Брюховецька Л. І. Давня і сучасна Україна в кіно Польщі / Л. І. Брюховецька // Кіно-Театр. - 2016. - № 3. - С. $15-18$.

7. Брюховецька Л. І. Найцікавіша історія в Свропі. Екранні версії / Л. І. Брюховецька. - Київ: Задруга, 2014. - 493 с.

8. Власть и образ. Очерки потестарной имагологии / Под ред. М. А. Бойцова и Ф. Б. Успенского. - СПб.: Алетейя, 2010. - 384 с.

9. Госейко Л. Історія українського кінематографа: 1896-1995: пер. $з$ фр. / Л. Госейко. - Київ: КІNO-КОЛО, 2005. - 464 с. 10. Грідасов П. Образ Леніна в кіно / П. Грідасов // Радянське кіно. - 1938. - № 2, березень. - С. 7-12.

11. Жукова А. С. Українське радянське кіномистецтво. 1930-1941 / А. Є. Жукова, Г. В. Журов. - Київ: Видавництво академії наук УРСР, 1959. - 236 с.

12. Савченко Я. Звенигора: збірник ст. про фільм («Звенигора» реж. О. Довженка) / Я. Савченко та ін. - Київ: ВУФКУ, 1928. - 48 с.

13. Ілляшенко В. Історія українського кіномистецтва / В. Ілляшенко. - Київ: «ВІК», 2004. - 386 с.

14. Історія українського кіно. - Т. 2: 1930-1945 / голов. ред. Г. Скрипник. - Київ: НАН України; ІМФЕ ім. М. Т. Рильського, 2016. - 448 с.

15. Історія українського радянського кіно: [в 3 т.] / редкол.: Т. В. Левчук, Б.С. Буряк та ін. - Київ: Наукова думка, 1986. - T. 1. - 214 c.

16. Корнієнко I. С. Українське радянське кіномистецтво. 1917-1929 / І. С. Корнієнко. - Київ: Видавництво академії наук УРСР, 1959. - 144 с.

17. Котова С. «Образ чужого» і «образ ворога»: «імагологія»в сучасних міждисциплінарних гумнітарних дослідженнях / С.Котова // Вісник Київського національного університету імені Тараса Шевченка. Історія. 2015. - № 4. - С. 20-24.

18. Кузюк О. М. Українське радянське кіно 1930-х років: суспільно-політичний аспект / О. М. Кузюк // Гілея. 2010. - T. 41. - № 11. - С. 123-128.

19. Культурне будівництво в Українській РСР. Важливіші рішення комуністичної партії і радянського уряду 1917-1959 рр.: [в 2 т.]. Редкол.: О. І. Євсєєв. - Київ: Державне видавництво політичної літератури УРСР, 1959. - T. 1. -883 c.

20. Луначарский А. В. Луначарский о кино: Статьи. Высказывания. Сценарии. Документы / А. В. Луначарский. - Москва: Искусство, 1965. - 366 с.

21. Нариси з історії кіномистецтва України / Редкол.: В. Сидоренко. - Київ: Інтертехнологія, 2006. - 864 с.

22. Полторацький О. Образовість у кіно / О. Полторацький (Озеров) // Кіно. - 1927. - № 1. - С. 12.

23. Посохов С. И. Этические проблемы исторической имагологии / С. И. Посохов // Історіографічні та джерелознавчі проблеми історії України. Професійна етика історика у міждисциплінарному просторі. - Дніпропетровськ: ЛІРА, 2014. - С. 115-131.

24. Примаченко Я. Л. Українське кіно 1920-х років у пошуках власних тем та смислів / Я. Л. Примаченко // Україна модерна: Міжнародний інтелектуальний часопис. - 2017. - 15 березня.

25. Про тематичний план. Резолюція наради при агітпропі ЦК КП(б)У // Кіно. - 1928. - № 11. - С. 16.

26. Росляк Р. В. До питання про українізацію вітчизняної кіногалузі (1920 - початок 1930-х років) / Р. В. Росляк // Студії мистецтвознавчі. - 2014. - № 1. - С. 128-134.

27. Росляк Р. В. Тематичне планування як засіб управління українським кінематографом (з досвіду 20-х років XX століття) / Р. В. Росляк // Вісник Національної академії керівних кадрів культури і мистецтв. - 2014. - № 2. - С. 271-275. 28. Сетар В. «П.К.П.» / В.Сетар // Кіно. - 1926. - № 8. - С. 15-17, 20.

29. Тримбач С. В. Кіно, народжене Україною. Альбом антології українського кіно / С. В. Тримбач. - Київ: Техніка, 2016. $-384 \mathrm{c}$.

30. Троцький Л. Д. Церква, водка и кинематограф / Л. Д.Троцький // Правда. - 1923. - 12 июля. - № 154.

31. Файзулін Я. Документи 3 архівів розкривають закадрові таємниці фільму-агітки «П.К.П.»- «Пілсудський купив Петлюру» / Я.Файзулін. - Режим доступу: http://www.memory.gov.ua/publication/dokumenti-z-arkhiviv-kgbrozkrivayut-zakadrovi-taemnitsi-filmu-agitki-pkp-pilsudskii-kup

32. Черняк Є. «Арсенал» / С. Черняк // Кіно. - 1929. - № 1. - С. 4-5.

33. Шугай М. «Трипільська трагедія» / М. Шугай // Кіно. - 1926. - № 4. - С. 11-12.

34. Що робитиме українське кіно 1928-1929 року. Орієнтований тематичний план ВУФКУ // Кіно. - 1928. - № 9. - С. $17-24$.

35. Щорс»: Збірник / Упоряд.: Ю. І. Солнцева, Т. Т. Дерев’янко. - Київ: Мистецтво, 1984. - 196 с.

36. Янчук Олесь: «Ми хочемо показати людям, що Петлюра - це не бандит, як стверджувала радянська пропаганда, а справжній український лідер» // Час і події. Молодіжне перехрестя. - 2017. - 22 червня. - № 309. 


\section{REFERENCES}

1. Avenarius, H.A. (1936). Problema khudozhnoho obrazu u filmakh O. P. Dovzhenka [The problem of artistic image in the films of O. P. Dovzhenko]. Kino, 4, 18-23 [in Ukrainian].

2. Bazhan, M. (1927). Lehendy ta istoriia [Legends and History]. Kino, 2, 21-22 [in Ukrainian].

3. Bezklubenko, S.D. (2001). Ukrainske kino: nacherk istorii [Ukrainian Cinema: The Review of History]. KNUKiM, Kyiv [in Ukrainian].

4. Berest, B. (1962). Istoriia ukrainskoho kina [The History of Ukrainian Cinema]. New York: Naukove tovarystvo im. T. Shevchenka [in Ukrainian].

5. Briukhovetska, L.I. (2013). «Zvenyhora»: ovolodinnia istorychnym chasom [«Zvenigora»: comes over the historical time]. Kinorezhyser svitovoi slavy. Kyiv: Lohos [in Ukrainian].

6. Briukhovetska, L.I. (2016). Davnia i suchasna Ukraina v kino Polshchi [Ancient and contemporary Ukraine in the films of Poland]. Kino-Teatr, 3, 15-18 [in Ukrainian].

7. Briukhovetska, L.I. (2014). Naitsikavisha istoriia v Yevropi. Ekranni versii. [The most interesting story in Europe. Onscreen version]. Kyiv: Zadruha [in Ukrainian].

8. Boytsov, M.A., \& Uspienskiy, F.B. (Eds.) (2010). Vlast i obraz. Ocherki potestarnoi imagologii [The Power and the Image. The Reviews on Potestary Imagology]. Saint Petersburg: Alateya [in Russian].

9. Hoseiko, L. (2005). Istoriia ukrainskoho kinematohrafu: 1896-1995 [The History of Ukrainian Cinematography: 1896-1995]. Kyiv: KINO-KOLO [in Ukrainian].

10. Hridasov, P. (1938). Obraz Lenina v kino [The image of Lenin in films]. Radianske kino, 2, 7-12 [in Ukrainian].

11. Zhukova, A.E., \& Zhurov, H.V. (1959). Ukrainske radianske kinomystetstvo. 1930-1941 [The Ukrainian Soviet Cinematic Art. 1930-1941]. Kyiv: Vydavnytstvo akademii nauk URSR [in Ukrainian].

12. Savchenko, Ya., Bazhan, M., Yakubovskyi, M., Dovzhenko, O., \& Khmuryi, V. (1928). Zvenyhora: zbirnyk [Zvenygora: the collection]. Kyiv: VUFKU [in Ukrainian].

13. Illiashenko, V. (2004). Istoriia ukrainskoho kinomystetstva [The History of the Ukrainian Cinematic Art]. Kyiv: «VIK» [in Ukrainian].

14. Skrypnyk, H. (Ed.) (2016). Istoriia ukrainskoho kino [The History of the Ukrainian Cinema]. (Vols. 2). Kyiv: NAN Ukrainy; IMFE M. T. Rylskoho [in Ukrainian].

15. Levchuk, T.V., Buriak, B.S. et al. (Eds.). (1986). Istoriia ukrainskoho radianskoho kino [The History of the Ukrainian Soviet Cinema]. (Vols. 3). Kyiv: Naukova dumka [in Ukrainian].

16. Korniienko, I.S. (1959). Ukrainske radianske kinomystetstvo. 1917-1929. [The Ukrainian Soviet Cinematic Art. 1917-1929]. Kyiv: Vydavnytstvo akademii nauk URSR [in Ukrainian].

17. Kotova, S. (2015). «Obraz chuzhoho» i «obraz voroha»: «imaholohiia» v suchasnykh mizhdystsyplinarnykh humanitarnykh doslidzhenniakh [The image of «Other» and the image of «Enemy»: the «imagology» in the contemporary interdisciplinary humanities works]. Bulletin of Taras Shevchenko National University of Kyiv. History, 4, 20-24 [in Ukrainian].

18. Kuziuk, O.M. (2010). Ukrainske radianske kino 1930-kh rokiv: suspilno-politychnyi aspect [The Ukrainian Soviet Cinema of 1930th: the social and political aspects]. Gileya, 41(11), 123-128 [in Ukrainian].

19. Yevsieiev, O.I. (Ed.). (1959). Kulturne budivnytstvo v Ukrainskii RSR. Vazhlyvishi rishennia Komunistychnoi partii i Radianskoho uriadu 1917-1959 rr. [The cultural building in Ukrainian SSR. The main decisions of Communist Party and Soviet government from 1917-1959]. (Vols. 2). Kyiv: Derzhavne vydavnytstvo politychnoi literatury URSR [in Ukrainian].

20. Lunacharsky, A.V. (1965). Lunacharsky o kino: Stat'i. Vyskazyvaniya. Stsenarii. Dokumienty. [Lunacharsky about the Cinema: Articles. Speeches. Screenplays. Documents.]. Moscow: Iskusstvo [in Russian].

21. Sydorenko, V. et al. (Eds.) (2006). Narysy z istorii kinomystetstva Ukrainy [The Sketches from the History of Ukrainian Cinematic Art]. Kyiv: Intertekhnologiia [in Ukrainian].

22. Poltoratskyi, O. (1927). Obrazovist u kino [The Imagery in the Cinema]. Kino, 1, 12 [in Ukrainian].

23. Posokhov, S.I. (2014). Eticheskiye problemy istoricheskoy imagologii [The ethical problems of historical imagology]. Istoriohrafichni ta dzhereloznavchi problemy istorii Ukrainy. Profesiina etyka istoryka u mizhdyscyplinarnomu prostori. Dnipropetrovsk: LIRA [in Russian].

24. Prymachenko, Ya.L. (2017). Ukrainske kino 1920-h rokiv u poshukah vlasnyh tem ta smysliv [The Ukrainian Cinema of 1920th in the search of their own themes and meanings]. Ukraina Moderna: Mizhnarodnyi intelektualnyi chasopys. Retrieved from: http://uamoderna.com/md/prymachenko-ukrainian-cinema [in Ukrainian].

25. Pro tematychnyi plan. Rezoliutsiia narady pry ahitpropi TsK KP(b)U. (1928). [About the thematic plan. Resolution of the meeting at the agitprop of the Central Committee of the Communist Party (Bolshevik) of Ukraine]. Kino, 11, 16 [in Ukrainian].

26. Rosliak, R.V. (2014). Do pytannia pro ukrainizaciiu vitchyznianoi kinohaluzi (1920 - pochatok 1930-kh rokiv) [About the question of ukrainization of the domestic film industry (1920th and the beginning of 1930th )]. Studii mystetstvoznavchi, 1, 128-134 [in Ukrainian]. 
27. Rosliak, R.V. (2014). Tematychne planuvannia yak zasib upravlinnia ukrainskym kinematohrafom (z dosvidu 20-kh rokiv XX stolittia) [The thematic planning as a cinema management method (from the experience of 1920th)]. Visnyk Natsionalnoi akademii kerivnykh kadriv kultury i mystetstva, 2, 271-275 [in Ukrainian].

28. Setar, V. (1926). «P.K.P.» [«P.K.P. »]. Kino, 8, 15-17; 20 [in Ukrainian].

29. Trymbach, S.V. (2016). Kino, narodzhene Ukrainoiu. Albom antolohii ukrainskoho kino [The Cinema, born in Ukraine. The Album of Anthology of the Ukrainian Cinema]. Kyiv: Tekhnika [in Ukrainian].

30. Trotskiy, L.D. (1923). Tserkva, vodka i kinematograf [The Church, Vodka and Cinematograph]. Pravda, 154, July 12 [in Russian].

31. Faizulin, Ya. (n.d.) Dokumenty z arkhiviv rozkryvaiut zakadrovi taiemnytsi filmu-agitky «PKP» - «Pilsudskyi kupyv Petliuru» [The documents from the archives reveal a backstage secret of the prop film «PBP» - «Pitsudski bought Petlura»] Retrieved from http://www.memory.gov.ua/publication/dokumenti-z-arkhiviv-kgb-rozkrivayut-zakadrovitaemnitsi-filmu-agitki-pkp-pilsudskii-kup [in Ukrainian].

32. Cherniak, Ye. (1929). «Arsenal» [«Arsenal»]. Kino, 1, 4-5 [in Ukrainian].

33. Shuhai, M. (1926). «Trypilska trahediia» [Trypillia tragedy]. Kino, 4, 11-12 [in Ukrainian].

34. VUFKU. (1928). Shcho robytyme ukrainske kino 1928-1929 roku. Oriientovanyi tematychnyi plan VUFKU [What will Ukrainian cinema perform in 1928-1929. Oriented thematic plan of the VUFKU]. Kino, 9, 17-24 [in Ukrainian].

35. Solntseva, Yu.I., \& Derevianko, T.T. (Eds.) (1984). «Shchors»: Zbirnyk [ «Shchors»: The Collection]. Kyiv: Mystetstvo [in Ukrainian].

36. Yanchuk, O. (2017). «My khochemo pokazaty liudiam, shcho Petliura - tse ne bandyt, yak stverdzhuvala radianska propahanda, a spravzhnii ukrainskyi lider» [We want to show people that Petlura was not an outlaw, as Soviet propaganda claimed, but a real Ukrainian leader]. Chas i podii. Molodizhne perekhrestia, 309, June 22 [in Ukrainian].

\section{Пижик Андрій Миколайович}

Кандидат історичних наук, доцент

Київський національний університет імені Тараса Шевченка

01033, Київ, вул. Володимирська, 60

\section{Pyzhyk Andrii}

PhD in History, Associate Professor

Taras Shevchenko National University of Kyiv

60, Volodymyrska Str., Kyiv, 01033, Ukraine

Email: pythyk@ukr.net

Цитування: Пижик А. М. Втілення в радянському художньому кіно образів «ворога» та «героя» періоду Української революції 1917-1921 рр. / А. М. Пижик // Науково-теоретичний альманах «Грані». - 2018. - Т. 21. - № 6. - С. 28-38.

Citation: Pyzhyk, A.M. (2018). Vtilennia v radianskomu khudozhnomu kino obraziv «voroha» ta «heroia» periodu Ukrainskoi revoliutsii 1917-1921 rr. [Visualization of the image of «enemies» and «heroes» from the period of the Ukrainian Revolution of 1917-1921 in Soviet narrative films]. Scientific and theoretical almanac «Grani», 21(6), 28-38. 